\title{
Obituaries
}

\section{Vladimir Aronovich Livshits (1923-2017)}

Iranian and Central Asian studies suffered a great loss on June 10, 2017. Vladimir Aronovich Livshits (Владимир Аронович Лившиц), full professor, the foreign member of the British Academy and the Academy of Sciences of Tajikistan, the eldest research fellow of the Institute of Oriental Manuscripts, and a member of the Advisory Board of Scrinium, died peacefully in his apartment in Saint Petersburg on his 94th year of life.

He was born on October 6, 1923 in Petrograd, in Liteyny district, in the family of an engineer. From his childhood, Vladimir Aronovich grasped some knowledge of Yiddish (which became useful later in conversation with German scholars such as W.B. Henning), but of course his native language was Russian. During Stalin's persecutions, his father was repressed but after several years in deportation returned to Leningrad (albeit with seriously damaged health) and lived until go years of age. Despite being son of a "political criminal," Livshits managed to enter a high school. First it was a technical university; during those young years already, however, his heart was attracted to oriental cultures, especially since his class-mate entered the Oriental department of the Philological faculty of the Leningrad State University. He studied externally Persian language, the fairy-tale collection of Țutti-nāmah, which was and still is the principal study book in the first year of the course, and enrolled into the second grade of the Iranian philology.

On June 22, 1941, Germany attacked the Soviet Union, and, since then, the World War II engaged almost the whole male population of the Soviet Union. Livshits, who was an expert in telling anecdotes of his life and of fellow scholars, did never narrate about the severe years of the war. He dug trenches, survived the first year of the siege of Leningrad, was in a hospital and on the front line, and finally returned to his home city and in 1945 resumed studies at the university. 
Apart from studying Persian and other oriental languages, and, of course, scholastics of Marxism, he attended many courses in general philology and linguistics taught by distinguished professors. Since 1946, he started his fieldwork in the framework of the "Tajik-Sogdian Archaeological Expedition" under the leadership of Alexander Yu. Jakubovski (1886-1953). During his university years, from which he graduated ahead of schedule, he was noticed by the budding Assyriologist Igor M. Diakonoff (1914-1991), whom Livshits considered his teacher.

Since 1948, Igor Diakonoff, his brother Mikhail M. Diakonoff (1907-1954), and Livshits were working on the recently discovered ostraca in Aramaic script from Nisa, the capital of the Parthian empire in the present-day Turkmenistan. They demonstrated that these texts were written not in a dialect of the Semitic Aramaic language, but in the Iranian, Parthian language in an Aramaic script with numerous heterograms, and served as a kind of labels for wine storage. The first stages of decipherment were done by the three scholars, the later by Igor Diakonoff and Livshits, and the last volumes of the complete edition of more than 2000 ostraca, with the images, transliteration, translation, and glossary, were published in the respectful series of the Corpus Inscriptionum Iranicarum by Livshits himself. In 2010, the dictionary of the proper names from Nisa and various papers of Livshits on Parthian language appeared as a book.

After having been graduated from the university, Livshits and Iosif M. Oranski (1923-1977; in his stories about post-war decades, Livshits always narrated in the first person plural, when his "we" meant "Oranski and me") attended the $\mathrm{PhD}$ course ("Aspirantura") under supervision of academician Alexander A. Freimann (1879-1968), both studying Pashto language. Livshits's dissertation was about personal pronouns in Pashto language, and it was published only in a handful of journal articles.

After the successful defense of their dissertations, Livshits and Oranski were directed to Stalinabad (today Dushanbe) in Tajikistan and returned to Leningrad only in 1958 / 59, thanks to the efforts of Bobojon G. Gafurov (19081977; the ex-first secretary of the Communist party of Tajikistan and later the director of the Institute of Oriental studies of the Soviet Academy of Sciences), and Igor Diakonoff. The years in Stalinabad were very fruitful, and the young city herself in the 1950s was extremely friendly and energetic according to memories of many scholars who started their carriers in Tajikistan. Livshits worked in the Institute of Language and Literature, and was a lecturer at the Pedagogical University. In those years he was engaged in compiling the dictionary accompanying the "Yaghnobi Folk-Tales" collected by M.S. Andreev and E.M. Peshchereva, where etymological remarks on this mountainous minority language, which show a number of similarities with the Middle Iranian 
Sogdian language, were included. During the preparation of the dictionary in Stalinabad, Livshits got acquainted with a street cleaner of Yaghnobi origin, and used him as a native speaker.

In 1932-1933, a major discovery was made in the mountains of central Tajikistan: a herdsman accidentally discovered a basket with old documents from the castle on Mount Mugh. In the next year, an archaeological expedition was sent to the castle and excavated many more documents. From the only Arabic document, it became clear that the archive belonged to a Sogdian prince Dewashtich who was executed in 722 during the Muslim conquest of Transoxiana. The major part of the documents was in Sogdian, it is still the only big find of texts in this Eastern Middle Iranian language found in Sogdiana proper. Freimann, the Doktorvater of Livshits, published a small selection of (mostly routine) documents. Considering the remaining part of them undecipherable due to their previously unknown cursive script, Freimann eventually gave to Livshits his set of photos of the documents. Livshits, still in Stalinabad, started working on them during his free time, which meant that he meditated over the photos on nights. This resulted into a series of articles followed with the editio princeps of juridical documents and letters from the archive of Mount Mugh (1962), which encompassed all the most important historical texts of the find. The texts included not only lists of daily expenditures and monotonous greeting letters, but also many contracts of various kinds, diplomatic correspondence, and even spy surveys of the early eighth century. In 1965, Mt. Mugh documents became the subject of Livshits's doctoral dissertation.

In the consequent years, Livshits continued his work on Sogdian epigraphy. He edited Buddhist manuscripts, coin legends, and a large set of epigraphy. His readings of the inscription on the walls of the famous "Ambassadors hall" in Afrasiab (Samarkand) were of greatest historical relevance. It established the dating of the hall to the Sogdian king Varkhuman (mid-seventh century) and its subject as the admission of ambassadors by the king. Other especially important epigraphical studies were dedicated to the Bugut stele commemorating the deeds of the first khagans of the Turkic khaganate in the last quarter of the sixth century (together with a Turkologist Sergey G. Kliashtorny, 1928-2014), the short business documents from Chilkhujra (Northern Tajikistan) dated to the years of king cwyws, or Kāwus, the last independent ruler of the kingdom Ustrushana before 822, and late inscriptions from Semirechye (Zhetysu). The largely corrected re-edition of the Mount Mugh documents together with minor epigraphical sources appeared in 2008; it received the prize of Ehsan Yarshater in 2010. In 2015, the English translation of the book "Sogdian Epigraphy of Central Asia and Semirechye," translated by T. Stableford and edited by 
N. Sims-Williams, was published under the aegis of the Corpus Inscriptionum Iranicarum.

Since 1958, Livshits worked as a research fellow at the Leningrad branch of the Institute of Oriental Studies of the Academy of Sciences (presently the Institute of Oriental Manuscripts), and was transferred to the consultant position in 2015. During these years, he continued to work on Sogdian and Parthian, but also on Middle Persian, Bactrian, and Chorasmian inscriptions. His impact was particularly significant for the latter, the tongue of a large oasis in the low course of the river Amu-daria. It is known through glosses and short phrases in dictionaries and law-books of Islamic time, but also through scarce epigraphy covering a huge time span between (at the latest) the second century BCE and the eighth century CE. Sergei P. Tolstov (1907-1976), the head of the Khorezm archaeological and ethnographical expedition, was the first to explain the script as a peculiar variation of the Aramaic writing used in Chorasmia, and to read some names, numbers, and ideograms. It was Livshits, however, who deciphered longer texts such as ossuary inscriptions from Tok-kala and Mizdakhkan, documents from Toprak-kala, labels on silver vessels found at Isakovka, many coin legends, and so on. Livshits's readings of Chorasmian inscriptions were highly valued by Walter Bruno Henning (1908-1967), the most renown Iranologist of his time, who was usually very harsh and ironic in his reviews.

For the first time Livshits got acquainted with Western colleagues at the 23 rd International Congress of Orientalists in Moscow in 1960, which was managed by Igor Diakonoff. From that time on, he had intensive exchange of correspondence and literature with Henning, Ilya Gershevitch (1914-2001), Vladimir F. Minorsky (1877-1966), Elias Bickermann (1897-1981), Richard N. Frye (19202014), D. Neil MacKenzie (1926-2001), and many others. He was universally accredited as the best epigraphist in the Middle Iranian languages. Apart from this waste field, Livshits published influential works on Iranian toponymy, on emergence of New Persian, on Tajik dialectology, on the Avestan society, on the administrative terminology of the Iranians, and on origins of the Old Turkic runic script.

The texts which Livshits used to publish were of secular nature but often reflecting Zoroastrian beliefs which appeared in personal names and some expressions such as swear in the name of god Mithra. Of course, the foreign religions which started to appear in these lands in the late Antiquity and the early Middle Ages, found their way into these texts as well. For example, he hypothesized a reference to the Buddhist sangha in the First Khaganate inscription at Bughut. He proposed to see the Hebrew name Yôsā in Parthian label on a vessel from Merv, he published a seal and an incised inscription with references to Manichaean bishops. He was the first to show that a significant group of 
inscriptions from Semirechye was written in a late variety of Sogdian language by Christian Turks. Previously, the discovery of Christian Sogdian writings was limited to the monastery of Bulayıq in Turfan oasis, whereas the Christian material from Semirechye was limited chiefly to Syriac and Turkic tombstone inscriptions of a later date. The material published by Livshits showed that the tradition of Syrian Christianity in Semirechye was rooted in an older period and displayed its own continuity.

With his brightness, humor and amiability, Livshits was always the life of the party, and many people around were attracted by him. He was most famed by anecdotes about himself and his colleagues, which covered reality into sometimes a Jewish chokhma, sometimes a Middle Asian fable. Some of his anecdotes were published by his disciple, a renown Iranologist Ivan M. SteblinKamensky.

Although Livshits did not officially teach (except his Stalinabad period), there was always a circle of interested younger scholars and students around him. He was exuberant in sharing his huge knowledge, lent books from his unique library, and was meticulous reviewer of drafts of his pupils (although I do not know any journal review published by Livshits safe early one in coauthorship). Many papers were published by Livshits in co-authorship with his colleagues, archaeologists, and students. He welcomed us, his pupils, mostly at home, organised there language courses, and always fed with sausages and buckwheat which he cooked masterfully. We also enjoyed hospitality (in a much more elaborate fashion) of his wife, Natalia G. Ptitsina, and his elder son Slava, who was his companion during the last years. His visits to archaeological excavations were memorable events, as well as his participation in conferences

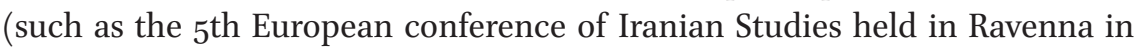
October 2003, during his 8oth anniversary). Livshits had no less than 18 aspirant $(\mathrm{PhD})$ students and 3 doctorands, although he preferred to call some of them his "pen-names" rather than his "students"; others are fruitfully working in Iranian Studies in various scholarly centers.

Until the last days of his long life Livshits had energetic working mood, was interested in new results from his colleagues, welcomed guests. He is remembered by many for his numerous brief telephone calls. Until these last days he was working on a monograph on Chorasmian onomastics. "Today I stay in bed, and tomorrow will sit up working" - were the words Vladimir Aronovich Livshits said four hours before his last gasp.

The bibliography of Livshits until the year 2005 is available at the web-site of the Institute of Oriental Manuscripts <http://www.orientalstudies.ru/rus/images/personalia/pdf/livshits.v.pdf>; additions until 2013 can be seen in the Festschift to his 9o-year anniversary: Commentationes Iranicae, Vladimiro f. Aaron 
Livschits nonagenario donum natalicum / Сборник статей к 9о-летию Владимира Ароновича Лившища, eds. S. Tokhtasev [Tokhtas'ev] and P. Luria [Lur'e], St. Petersburg: Nestor-Istoria, 2013, pp. 11-13.

\section{Pavel Lurje}

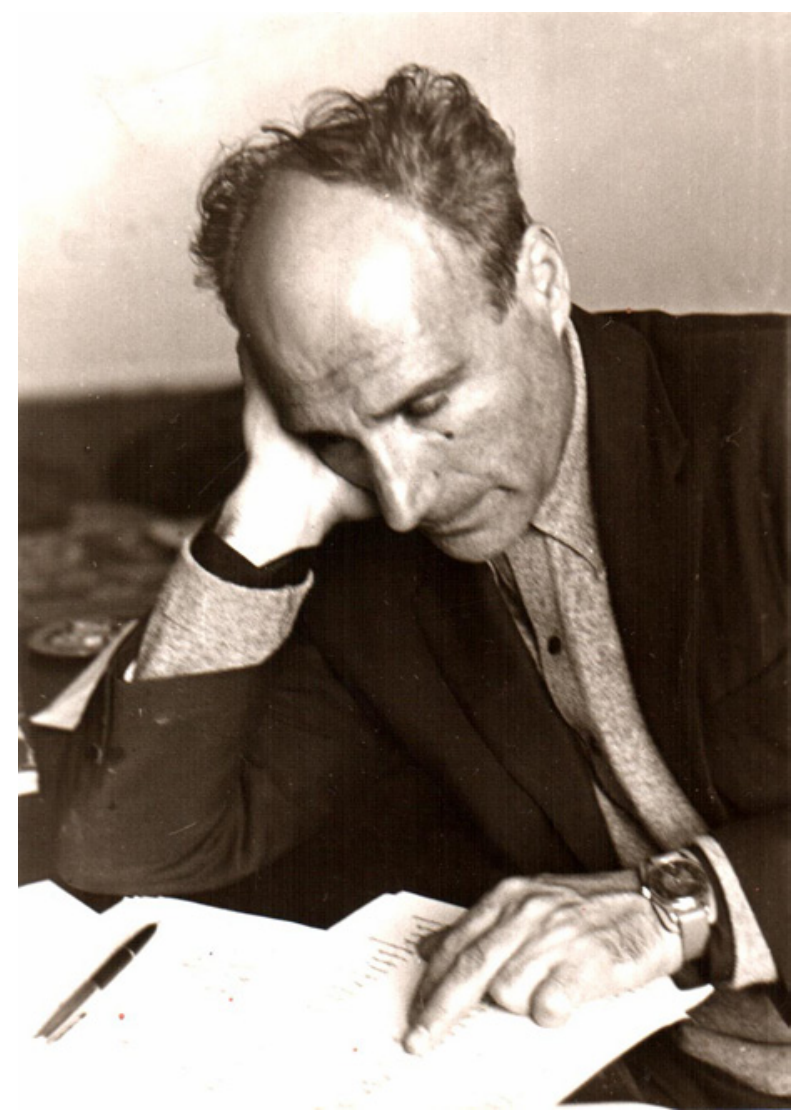

Vladimir Aronovich Livshits in the 1980s. From the photo archive of the Institute of Oriental Manuscripts. 